Article

\title{
Subjective Well-Being and Psychosocial Adjustment: Examining the Effects of an Intervention Based on the Sport Education Model on Children
}

\author{
Pablo Luna ${ }^{1}$ (D) Alba Rodríguez-Donaire ${ }^{1}$, Débora Rodrigo-Ruiz ${ }^{2}$ and Javier Cejudo ${ }^{1, *(1)}$ \\ 1 Department of Psychology, Faculty of Education, University of Castilla-La Mancha, 13071 Ciudad Real, \\ Spain; pablo.luna@uclm.es (P.L.); Alba.Rodriguez11@alu.uclm.es (A.R.-D.) \\ 2 Department of Research and Diagnostic Methods in Education, Faculty of Education, International \\ University of La Rioja (UNIR), 26006 Logroño,, Spain; debora.rodrigo.ruiz@unir.net \\ * Correspondence: manueljavier.cejudo@uclm.es; Tel.: +34-926295300 (ext. 3215)
}

Received: 14 May 2020; Accepted: 2 June 2020; Published: 3 June 2020

\begin{abstract}
The current study aims to evaluate the effectiveness of an intervention based on the Sport Education model, compared to an intervention based on the traditional model of Direct Instruction in children. The intervention was carried out during school hours for 18 sessions of 50-min each. The sample was made up of 146 children aged $10-12$ years $(M=10.78$ years; $S D=1.07$ years). Participants were randomly assigned to the experimental group $(n=87)$ and a control group $(n=59)$. A quasi-experimental design with repeated pretest and posttest evaluations with the control group was implemented. The Positive and Negative Affect Scale for children and adolescents (PANASN) was used to assess the affective component of subjective well-being. The Child and Adolescent Behavior Assessment System (BASC) was used to assess psychosocial adjustment. The results showed significant improvements in the affective component of subjective well-being and a reduction in anxiety in favor of the experimental group. Our current results show the methodological and practical efficacy of a Sport Education intervention.
\end{abstract}

Keywords: physical education; sport education model; children; subjective well-being; psychosocial adjustment

\section{Introduction}

Subjective well-being encompasses two dimensions [1], the affective dimension (positive and negative affect), and the cognitive dimension (satisfaction with life) [1,2]. Likewise, subjective well-being [2] has been identified with positive emotions and the absence of negative emotions [3]. It could also be considered as an interesting predictor of physical health, interpersonal relationships, and the correct bio-psychosocial development of individuals [4]. Some authors argue for the need and importance of improving subjective well-being in the population [5]. It is then appropriate that this psychological construct is becoming prominent in educational research, and its influence in social [6] and school contexts [7] is relevant.

On the other hand, McMahon et al. [8] argue that physical activity and sport practice are positively related to well-being and negatively related to psychosocial indicators such as anxiety. In this line of thought, subjective well-being, as a critical factor in the educational context, is related to variables such as psychosocial adjustment [9,10]. Rodríguez-Fernández et al. [11] interpret psychosocial adjustment as an association of school adjustment (or school commitment) and subjective well-being. The psychosocial adjustment construct refers to people's ability to adapt to the demands of the social context [12]. In recent years, a considerable increase in behavioral and adaptive problems has 
been observed in children in the family and socio-school environment, being a cause of concern for educational institutions and society in general [11]. For this reason, it is essential to promote a positive psychosocial adjustment of the students in order to promote a healthy adaptation to the physical, psychological, social, and affective environments [13], while also becoming a beneficial factor for subjective well-being [14].

A primary objective within the educational context should be to promote active and participatory lifestyle habits [15]. Some studies establish a positive relationship between physical sport activity and some variables such as subjective well-being [16] and health and psychosocial adjustment [16,17]. Therefore, increasing healthy physical and sport practices among less active youth should be a crucial objective of community and school institutions and interventions to promote well-being [8].

Escalié et al. [18] emphasize the importance of balanced student development. The educational system needs to foster motivating and competent environments that are significant for a positive psychosocial adjustment and, therefore, for the integral development of the student's personality [19]. However, internalizing and externalizing adaptive behaviors in children are increasing, and the intervention processes are not always effective [20]. In this sense, our study is in line with educational programs that promote balanced student development and aim to improve the different dimensions of children's evolutionary development: the physical dimension, cognitive dimension, and affective-social dimension [21]. It is essential to promote motivating, participatory, and active interventions [22] driven by effective pedagogical models [23].

Several pedagogical models share these same characteristics [21]. Among the most suitable [23] is the Sport Education model (SEM) [24,25] articulated as a curricular teaching model within a quality physical education that favors an effective motor, affective, and social commitment in students [14]. The SEM is understood within a pedagogical framework based on practice, whose two main objectives are: (1) allowing students to develop authentic sport experiences, simulating the real aspects of the game, and adapting them to the educational context; (2) encouraging students to acquire competence, enthusiasm, and physical sport culture [26]. This is a constructivist and cooperative student-centered pedagogy [27] instead of repetitive sport experiences developed in physical education based on the traditional model of Direct Instruction focused on teachers $[21,27,28]$.

The SEM has attracted considerable interest in recent years from researchers and educational professionals, with different systematic reviews published (e.g., [29,30]). In the review by Hastie et al. [29], improvements using the model (SEM) were confirmed in: physical fitness, knowledge, understanding, and technical-tactical ability. In other words, improvements included effective learning of the sport game; personal and social development; positive and attractive attitudes towards physical education (e.g., enthusiasm and enjoyment); and educational values (e.g., respect, affinity, fairness, fair play, etc.). Similarly, other more recent reviews confirm a positive impact of SEM on physical, social, and emotional development [31,32], ethical development [33], as well as in motivational indicators [34]. Furthermore, authors such as Sierra-Díaz et al. [35], in their meta-analysis, show improvements in motivation towards physical and sport activity, belonging and social responsibility, autonomy, and organization using the SEM.

A review of the scientific literature shows the scarcity of studies on educational interventions in physical education, based on the SEM, that evaluate the effects of the variables of the present investigation (subjective well-being and psychosocial adjustment). However, based on the scientific literature, it would be logical to think of possible positive effects of the SEM on these variables. The prior results suggest that, from an effective and efficient implementation of the model $[36,37]$, they show positive effects: (a) at the physical-motor level [38,39]; (b) at the affective level [40]; and (c) at the social level $[28,41,42]$. Likewise, the SEM has been revealed in the school context as a teaching model capable of causing positive effects on socio-personal indicators (cooperation, empathy, self-discipline) [29] as well as on knowledge and physical $[43,44]$ and sport performance indicators $[45,46]$. Likewise, various studies have shown that interventions based on the SEM show a positive impact on variables of psychosocial nature, such as motivational processes [34,47,48]; basic psychological needs [42,49,50]; 
cohesion skills and social relationships [28,41,42]; trait emotional intelligence dimensions and motivational mediators [40,51]; and a decrease in passive behaviors, aggressiveness, and violence, improving the relationship and social responsibility among the participants [52]. However, regarding the statistical analysis of the data, in most of these previous studies, the change/gain score through analysis of variance (ANOVA) (that is, posttest minus pretest) was used as a criterion group comparison. In this line, some authors such as Pérez-González et al. [53] recommend using covariance (ANCOVA) where the covariate is the baseline or pretest score, controlling for the possible effect of the pretest score on the results of the posttest. Criteria followed in the present study are in the same line as other authors (e.g., [28,40,41,52]).

Taking into account the above, the objective of the current study was to evaluate the impact of a SEM-based educational intervention in children, compared to an educational intervention based on the traditional model of Direct Instruction (TM-DI) on: (1) subjective well-being in its affective dimension; and (2) psychosocial adjustment with the indicators of depression, anxiety, and social stress. The hypotheses focused on the fact that said educational intervention will improve the participants' affective dimension of the experimental group's subjective well-being (Hypothesis 1) and psychosocial adjustment (depression, anxiety, and social stress) (Hypothesis 2).

\section{Materials and Methods}

\subsection{Design}

The study was carried out using a quasi-experimental design with repeated measurements (pretest and posttest) and a control group. Participants were randomly assigned to the experimental group (EG) and the control group (CG) through a cluster-randomized controlled trial.

\subsection{Participants}

The sample was obtained through a non-probabilistic incidental sampling method and was made up of 167 children, aged between 10 and 12 years (mean age $(M)=10.78$; standard deviation $(S D)=1.07$ ) (refer to Table 1).

Table 1. Sample Description.

\begin{tabular}{cccc}
\hline \multirow{3}{*}{ Age } & & $\boldsymbol{n}$ & $\boldsymbol{\%}$ \\
& 10 & 79 & 54.11 \\
& 11 & 46 & 31.51 \\
\multirow{2}{*}{ Gender } & 12 & 21 & 14.38 \\
& Male & 67 & 45.89 \\
& Female & 79 & 54.11 \\
\hline
\end{tabular}

The inclusion criteria ( $n=146)$ for the study were: (1) regular attendance at the school; (2) the written informed consent from the family (or legal guardian). The exclusion criteria $(n=21)$ were: (1) physical disability with official medical proof; (2) students with more than $30 \%$ truancy; (4) students sanctioned for disciplinary reasons by the educational center; (5) failure to obtain informed written consent from family (or legal guardian); (6) not completing the evaluation questionnaires adequately. The 146 participants who met and completed the study under research with the proposed criteria were randomly assigned to the EG through a cluster-randomized controlled trial $(n=87)$ or to the CG $(n=59)$. The differences in the two conditions (experimental group and control) were not significant by age $(\chi 2=1.17 ; p>0.05)$ nor by gender $(\chi 2=1.76 ; p>0.05)$. Participant flow is displayed below (refer to Figure 1). 


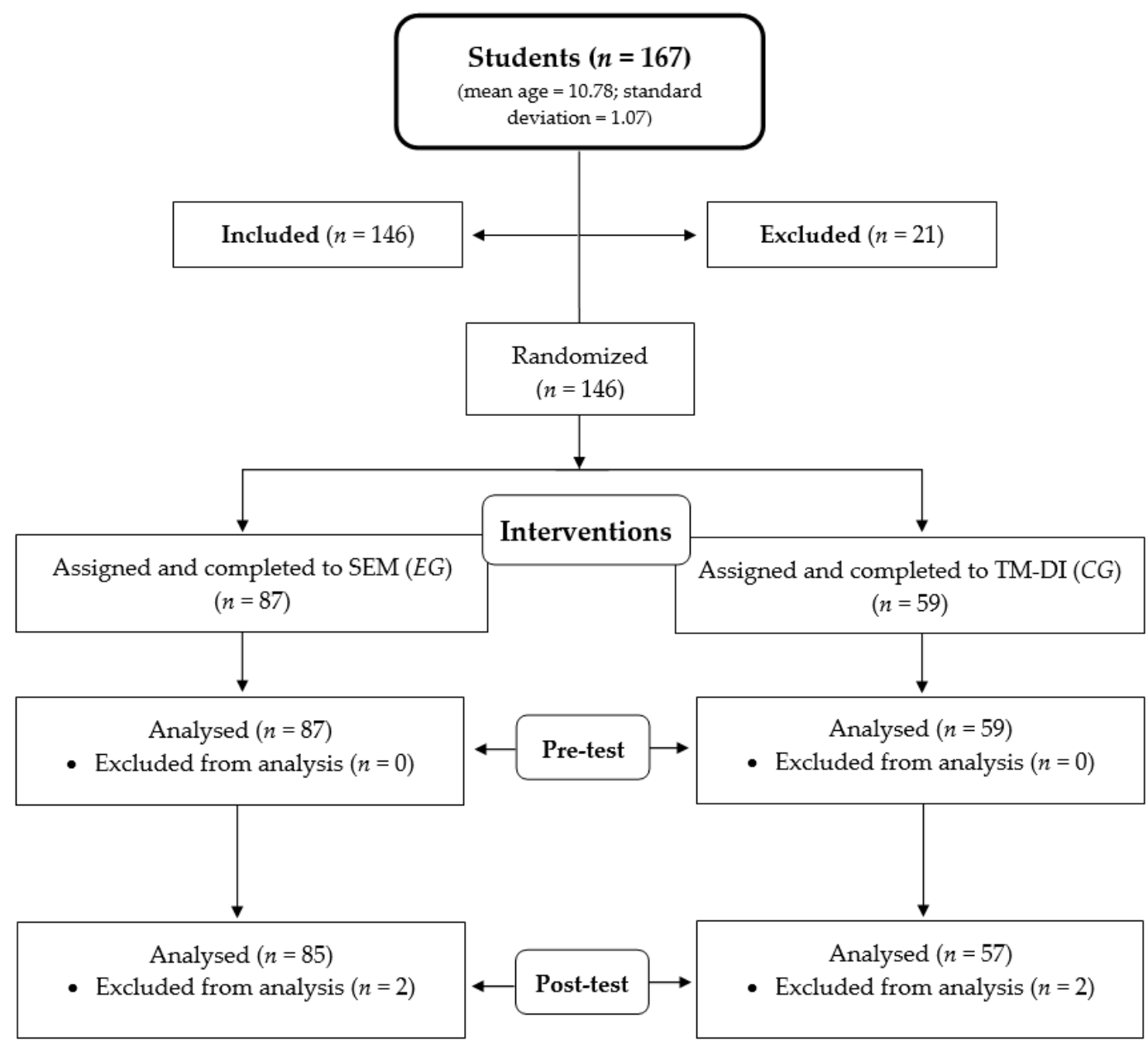

Figure 1. Flow diagram: interventions based on the Sport Education model (SEM) (EG = experimental group) and traditional model of Direct Instruction (TM-DI) (CG = control group).

\subsection{Research Instruments}

For this educational research, two measures have been used to evaluate the variables under study, with adequate psychometric parameters of reliability and validity.

Positive and Negative Affect Schedule (PANAS) [54]. The PANAS version validated in Spanish by Sandín [55] for use with children and adolescents (PANASN) was used to evaluate subjective well-being in its affective dimension. It is made up of 20 items and presents a two-factor structure: positive affect (e.g., "I am interested in people or things") and negative affect (e.g., "I am afraid") with 10 items for each subscale. The measure consists of three response alternatives, described as «Never» (1), «Sometimes» (2), and «Often» (3). In the current study, the internal consistency calculated using Cronbach's alpha was $\alpha=0.81$ for positive affect and $\alpha=0.78$ for negative affect.

Behavior Evaluation System for Children and Adolescents (BASC) [12]. The BASC-S2 questionnaire was used in its self-report version for children, made up of a total of 146 items, to evaluate the psychosocial adjustment variable. The BASC is a multidimensional instrument that measures numerous aspects of behavior and personality, including both positive (adaptive) and negative (clinical) dimensions. It consists of different adaptive subscales (which assess the positive fit) and clinical subscales (which assess mismatch), where participants rate statements that reflect their personal thoughts and feelings as true or false. In the current study, some clinical scales for evaluating negative or undesirable characteristics were used, such as: (a) depression: feelings of sadness, loneliness, and poor enjoyment of life, sometimes as a consequence of anxiety and stress processes (high scores indicate a problematic level of depression); (b) anxiety: presence of feelings of fear, obsessive thoughts, 
and generally irrational worries (high scores mean that the individual suffers emotionally and may experience stress reactions that make them explode due to some triviality); and (c) social stress: levels of stress (e.g., tension, anxiety, etc.) that children suffer in interpersonal relationships (high scores indicate problems related to shyness, introversion, social anxiety, and irritability). The current research used an instrument with adequate and satisfactory psychometric properties for the socio-emotional evaluation of Spanish children and adolescents in the school and clinical context $[12,56]$.

\subsection{Procedure}

The study was carried out in four periods. In the first one, the educational intervention program was designed. Second, the pretest evaluation was carried out (the timing for the tests was between 50-55 $\mathrm{min}$ ) both in the experimental and control groups, regulating students' fatigue with scheduled breaks. In the third period, the educational intervention based on the SEM was applied to the experimental group, and the intervention based on the traditional model of Direct Instruction (TM-DI) to the control group. In the last period, at the end of the interventions, the posttest evaluation was performed (the time of the tests was between $50-55 \mathrm{~min}$ ) in both groups, with scheduled breaks to avoid student fatigue.

The research was developed following the ethical code of the University of Castilla-La Mancha (Spain) following the international guidelines on experiments with human subjects described in the Nuremberg Code and the Declaration of Helsinki. As it was a study located within an educational context, it was authorized by the management team, the school council, and the participating school faculty. Also, constant telephone contact was maintained with the management team of the center for supervision and coordination of the project. As an essential requirement to participate in the research project, written informed consents were delivered to the center and requested to be signed by a parent or legal guardian. Likewise, the requirements of ethical confidentiality were respected and guaranteed by the participants' voluntary and anonymous nature (ethical guidelines of the American Psychological Association [APA], 2019; Personal Data Protection Law of the Research Ethics Committee on Human Beings, CEISH).

\subsection{Interventions}

\subsubsection{Intervention Based on the Sport Education Model (SEM)}

This is the educational intervention designed and implemented in the experimental group, applying an adaptation of the intervention published by Luna et al. [40]. It was developed according to the structure and essential characteristics of the SEM [25]: (1) season: a teaching unit of higher duration compared to the usual ones in physical education. A competitive plan is followed divided into three phases (preseason, competition, and final); (2) affiliation: grouping into teams with cooperative and socializing work maintained throughout the season (feeling of belonging to the group); (3) formal competition: as a relevant feature for practical experience and technical-tactical knowledge of physical and sport activity; an authentic sport experience is developed where relevant and real aspects of a formal sport competition are introduced to students; (4) data recording: process of evaluation and recording of sport performance, knowledge, and behavior; (5) final event: practical demonstration of the evolution in the advances and results obtained; (6) festivity: a festive atmosphere through symbolism (songs, hymns, etc.), rituals (shaking hands, group photos, etc.) and sport celebration (awards ceremony, trophies, self-built certificates, etc.). This structure is seen in Table 2. In this sense, the intervention followed the recommendations proposed by Hastie and Casey [37].

The intervention was developed with a sport education teaching unit (season) during school hours for two months (2-3 sessions per week for eight weeks) for a total of 18 sessions of $50 \mathrm{~min}$ of duration. The theoretical and practical sessions were applied with children for the subject of physical education, in an educational center within an urban environment and with a medium socio-cultural level. The teaching staff responsible for developing said intervention have nine years of teaching 
experience and four years of applying sport education. Similarly, the educational experience was controlled and examined by external researchers, in line with Sinelnikov's suggestions [57]: (1) personal and virtual contact regarding the problems that arose during the research; (2) regular inspections of the school center; (3) weekly analysis and verification of the investigation process.

The season was implemented through a divided court or net team sport, called Polskie ringo $[40,58]$. This alternative sport was carried out with heterogeneous and permanent groups. Likewise, the game's distribution was developed in different sport spaces modified, reduced and adapted to the ages of the participating children, and divided into two equal parts by volleyball nets. It is a team game where players have to receive, grab, and throw a ring (that they have built by themselves) to the other field, and it must touch the ground to score. The use of an innovative sport, unknown to children, made it easier for all students alike to start with similar sport training and technical-tactical knowledge. Likewise, alternative and team sports such as Polskie ringo adapt effectively to the educational environment, being collaborative, motivating, socializing, and flexible with their different skills $[58,59]$.

The participating students of each school year were randomly distributed in teams of five members, based on the principle of homogeneity in motor ability and gender [60]. Throughout the season, general roles common to all participants were assigned on the one hand: (a) player role, active and participatory; and (b) referee role: responsible for the registration of time, the minutes and reports of the game, in addition to complying with the regulations governing the game (with an emphasis on a fair play). The referee role constituted a rotating team responsibility role, carried out at least once by each team during the formal competition phase. This role played was key for the students, improving their understanding of fair play and fostering their empathy with the referee team when they acted as players. On the other hand, other specific roles of responsibility within the team were also assigned to the participants: (a) captain: team captain, whose functions are coordination and mediation; (b) audiovisual reporter: official journalist of the season, responsible for all the information and the management of a didactic blog, previously created by the faculty for the sport event; (c) coach: physical trainer whose function is to design, direct and control the previous and final physical sport warm-ups in the practical sessions, in addition to being responsible for the sport equipment used; and (d) celebration committee: organization event management involving all participants (e.g., organization of the final event).

In short, the application of active and cooperative methodologies, promoting the feeling of belonging to a team, together with positive reinforcements such as the final festival are crucial to explaining the motivation experienced by the students [34]. Likewise, it is essential to highlight, on the one hand, the guiding role of the teacher, and on the other hand, the active and autonomous role of the students, who act as the main protagonist of the teaching-learning process through their active participation and with the attribution of responsibility roles [25].

\subsubsection{Intervention Based on the Traditional Model of Direct Instruction (TM-DI)}

This is the educational intervention designed and implemented in the control group, developed using a traditional teaching-learning methodology $[21,28]$ following a traditional model of Direct Instruction $[27,32,48]$.

The intervention (TM-DI) was carried out through a teaching unit, following the usual curricular programming of the physical education department of the participating school. Likewise, it was applied during school hours, with a duration similar to the previous intervention (refer to Table 2). The theoretical and practical sessions were developed for children in the class of physical education, in the same educational center. The teachers responsible for carrying out this intervention had 12 years of teaching experience and had no previous SEM experience.

The teaching unit was also implemented with the Polskie ringo, with no working groups or permanent teams or responsibility roles being developed. In the same way, more active and total control was generated by the teachers regarding: (1) presentation, introduction and explanation of 
the tasks; (2) educational management; (3) methodological organization; (4) structure of activities; and (5) evaluation. Regarding the traditional model of Direct Instruction, the main characteristics were: (a) teaching-learning processes based, on the one hand, on a directive and instructive teaching function; and on the other hand, a passive function of students, determined by follow-up and search for these towards the teacher's instructions; (b) communicative processes characterized by a unidirectional and expository role of the teacher towards the students; (c) theoretical and practical sessions directed and structured solely by teachers, with rote and repetitive learning; (d) teaching style of homework assignment with the objective of learning specifically technical foundations of the sport chosen by the faculty (e.g., pass, throw, catch, etc.); (e) rhythm imposed by teachers, with an external, unidirectional, and outstanding teaching position regarding the group of students; (f) generalized teaching that did not individualize, using the sport equipment provided by the educational center (non-use of self-built materials by the students); (g) prescriptive feedback; and (h) situations of decontextualized activities and play, without experiencing authenticity, practiced individually or in pairs.

These traditional and control pedagogical approaches (TM-DI) are usually characterized by not focusing their intervention on children's autonomy and their intergroup interaction [48], reporting low levels of motivation [28], and a decrease in satisfaction and significant learning in physical education [21].

Table 2. Sequencing of session content in the educational interventions.

\begin{tabular}{|c|c|c|}
\hline SESSION & $\begin{array}{l}\text { Intervention with Sport Education Model (SEM) } \\
\text { (Experimental Group) }\end{array}$ & $\begin{array}{c}\text { Intervention with Traditional Model of } \\
\text { Direct Instruction (TM-DI) } \\
\text { (Control Group) }\end{array}$ \\
\hline $1-2$ & $\begin{array}{l}\text { - Introduction of the SEM, the sport developed by } \\
\text { teams (Polskie ringo), and the roles of } \\
\text { responsibility, with digital and audiovisual } \\
\text { support (ICT). } \\
\text { Explanation and delivery to the students of the } \\
\text { teaching material that will be used (e.g., } \\
\text { personalized folders with educational themes, } \\
\text { party minutes, contingency contracts, party } \\
\text { reports, etc.). } \\
\text { Organization and division of teams in a random } \\
\text { way. The working groups were permanent with } \\
\text { the assignment of team names following a } \\
\text { didactic and transversal theme (e.g., characters } \\
\text { from the Quixotic literature). } \\
\text { Designation and random distribution of } \\
\text { responsibility roles. }\end{array}$ & $\begin{array}{l}\text { Presentation and explanation by the } \\
\text { teachers of the teaching unit } \\
\text { implemented with the Polskie ringo. } \\
\text { General explanation of the educational } \\
\text { intervention to students: objectives, } \\
\text { content, and evaluation of the } \\
\text { teaching unit. } \\
\text { Distribution of students individually, } \\
\text { in pairs, and in small groups (no } \\
\text { permanent working groups are } \\
\text { established). }\end{array}$ \\
\hline $3-4$ & $\begin{array}{l}\text { Theoretical explanation with a digital whiteboard } \\
\text { (audiovisual) of how the students will carry out } \\
\text { the self-construction of the materials applied in } \\
\text { the intervention (e.g., Polskie ringo rings, } \\
\text { trophies, medals, etc.). } \\
\text { Practical explanation from the faculty on how to } \\
\text { make such materials (e.g., Polskie ringo rings, } \\
\text { certificates, etc.). } \\
\text { Construction by the students (self-construction) } \\
\text { of the materials in a cooperative way (permanent } \\
\text { groups/work teams). }\end{array}$ & $\begin{array}{l}\text { - Instructional and direct introduction } \\
\text { and explanation by teachers of: (a) the } \\
\text { general and specific characteristics of } \\
\text { the operation of the game (Polskie } \\
\text { ringo); (b) the regulations of the } \\
\text { Polskie ringo; and (c) sport equipment } \\
\text { used and provided by the school. } \\
\text { Practical activities for developing } \\
\text { individual and pair technical skills } \\
\text { (repetitive and rote): displacement I-II. }\end{array}$ \\
\hline
\end{tabular}


Table 2. Cont.

\begin{tabular}{|c|c|c|}
\hline $5-8$ & $\begin{array}{l}\text { - Initial warm-up and final stretching in each } \\
\text { session (directed by the students with the coach } \\
\text { role). These tasks should be applied through } \\
\text { reduced and modified physical activity and } \\
\text { sport games. } \\
\text { Practical team sessions to learn essential } \\
\text { technical-tactical skills in the game of the Polskie } \\
\text { ringo (displacement, coordination, pass, } \\
\text { reception, serve, etc.). } \\
\text { Functional application of roles in the different } \\
\text { active, participative, and cooperative tasks carried } \\
\text { out by the teams (e.g., captain: in the game of } \\
\text { attack and defense; referee: in the rules of } \\
\text { the game). } \\
\text { Sessions ended with interactive assemblies for } \\
\text { reflection and understanding (teacher-students } \\
\text { and vice versa), to work, for example, positive } \\
\text { feedback, active listening and error-learning. }\end{array}$ & $\begin{array}{l}\text { Teacher-directed technical warm-up } \\
\text { and stretching. } \\
\text { Practical activities for developing } \\
\text { individual and pair technical skills } \\
\text { (repetitive and memoiristic): } \\
\text { coordination I-II. } \\
\text { Practical activities for developing } \\
\text { individual and pair technical skills } \\
\text { (repetitive and memoiristic): pass and } \\
\text { reception I and II. } \\
\text { Practical activities for developing } \\
\text { individual and pair technical skills } \\
\text { (repetitive and memoiristic): catch, } \\
\text { serve, and throw. } \\
\text { The teachers, during the development } \\
\text { of the practical activities, gave } \\
\text { instructions to the participants on how } \\
\text { to correct and improve motor behavior. }\end{array}$ \\
\hline $9-15$ & $\begin{array}{l}\text { - Training team sessions with friendly Polskie ringo } \\
\text { games through educational competition } \\
\text { (emphasis on fair play and respect for the } \\
\text { opponent). } \\
\text { Responsibility role training (e.g., referee). } \\
\text { Development of authentic sport elements (e.g., } \\
\text { match minutes; interviews; etc.). } \\
\text { - Formal competition: } 5 \text { vs. } 5 \text { league format } \\
\text { (Round Robin). }\end{array}$ & $\begin{array}{l}\text { - } \quad \text { Warm-ups and stretches directed by } \\
\text { the teachers. } \\
\text { - } \quad \text { Tactical skill practice session } 1 \text { vs. } 1 \\
\text { - } \quad \text { Thrical skill practice session } 2 \text { vs. } 2 \text {. } \\
\text { between rotating pairs. } \\
\text { - } \quad \text { imultaneous Polskie ringo games by } \\
\text { rotating pairs. }\end{array}$ \\
\hline $16-17$ & $\begin{array}{l}\text { - Formal competition (semifinal and final): } 5 \text { vs. } 5 \\
\text { league format (Round Robin). } \\
\text { - Continuous and formative evaluation. }\end{array}$ & $\begin{array}{l}\text { Individual practical evaluation } \\
\text { (technical-tactical learning acquired). }\end{array}$ \\
\hline 18 & $\begin{array}{l}\text { - Celebration of the final event (organized by the } \\
\text { role of celebration committee). } \\
\text { Educational prizes, trophies, certificates, and } \\
\text { medals were presented, made by the } \\
\text { students themselves. }\end{array}$ & - $\quad$ Theoretical individual evaluation. \\
\hline
\end{tabular}

\subsection{Data Analysis}

First, the normality of the variables under study was calculated with the Kolmogorov-Smirnov test, all adjusting to the assumption of normality (analyzes performed with a 95\% confidence interval). Second, the reliability evidence was calculated with the Cronbach's alpha reliability coefficient $(\alpha)$. Third, to determine the impact of the pilot program, the following statistical analyses were carried out: (1) multivariate analysis of variance (MANOVA) with the total pretest scores of the variables under study, to confirm possible starting (initial) differences between the participants of the experimental group (EG) and control group (CG); (2) descriptive ( $M=$ mean; $S D=$ standard deviation) and variance (ANOVA) analyses with each of the scores obtained for the instruments used during the pretest phase; (3) in order to show significant improvements between the experimental and control groups, a multivariate analysis of covariance (MANCOVA) was calculated on the set of variables investigated; (4) descriptive analysis and analysis of covariance (ANCOVA: covariating the pretest scores) with the posttest scores; (5) finally, the effect size of the differences was analyzed according to the criteria set forth by Cohen [61] (low < 0.50; medium 0.50-0.79; big $\geq 0.80$ ).

\section{Results}

The multivariate analysis of variance (MANOVA) results did not reveal statistically significant differences between the groups (EG and CG) before the intervention, Wilks' Lambda, $\Lambda=0.337$; $\mathrm{F}_{(7,139)}=0.419 ; p=0.497$, with a low effect size $(d=0.018 ; r=0.03)$. 


\subsection{Pretest Analysis}

The pretest phase results (ANOVA) confirmed that before starting the educational intervention, there were no statistically significant differences in any of the variables under study (refer to Table 3).

Table 3. Mean, standard deviation, analysis of variance (ANOVA), analysis of covariance (ANCOVA), and effect size for the differences in the means (Cohen's $d$ ) in the variables under study (subjective well-being and psychosocial adjustment) in the experimental and control groups.

\begin{tabular}{|c|c|c|c|c|c|c|c|c|c|c|c|c|c|c|}
\hline & \multicolumn{7}{|c|}{ PRETEST } & \multicolumn{7}{|c|}{ POSTTEST } \\
\hline & \multicolumn{2}{|c|}{ Experimental } & \multicolumn{2}{|c|}{ Control } & \multicolumn{3}{|c|}{ ANOVA } & \multicolumn{2}{|c|}{ Experimental } & \multicolumn{2}{|c|}{ Control } & \multicolumn{3}{|c|}{ ANCOVA } \\
\hline & $\mathbf{M}$ & SD & $\mathbf{M}$ & SD & $F$ & $p$ & $d$ & $\mathbf{M}$ & SD & $\mathbf{M}$ & SD & $F$ & $p$ & $d$ \\
\hline \multicolumn{15}{|l|}{$\operatorname{SWB}(n=143)$} \\
\hline Positive affect & 22.26 & 5.00 & 22.71 & 4.15 & 6.811 & 0.146 & 0.10 & 26.48 & 2.93 & 24.61 & 3.23 & 5.088 & 0.018 & 0.61 \\
\hline Negative affect & 18.92 & 3.72 & 18.54 & 3.76 & 0.853 & 0.271 & 0.10 & 16.81 & 3.92 & 18.38 & 4.06 & 1.442 & 0.040 & 0.39 \\
\hline \multicolumn{15}{|l|}{ PA $(n=135)$} \\
\hline Depression & 47.57 & 10.41 & 47.40 & 10.51 & 1.045 & 0.445 & 0.02 & 47.02 & 11.57 & 47.46 & 11.35 & 0.573 & 0.258 & 0.04 \\
\hline Anxiety & 40.68 & 10.74 & 40.36 & 10.77 & 0.638 & 0.547 & 0.03 & 38.21 & 10.91 & 41.27 & 10.85 & 1.385 & 0.027 & 0.28 \\
\hline Social Stress & 47.75 & 10.75 & 47.83 & 10.59 & 1.127 & 0.489 & 0.01 & 47.10 & 10.46 & 48.36 & 10.57 & 0.982 & 0.875 & 0.12 \\
\hline
\end{tabular}

SWB = Subjective Well-Being; PA = Psychological Adjustment; $\mathrm{M}=$ Mean; SD = Standard Deviation.

\subsection{Posttest Analysis}

The multivariate analysis of covariance (MANCOVA) results in the pretest and posttest phases did not reveal statistically significant differences between the two groups (EG and CG), Wilks' Lambda, $\Lambda=0.993 ; \mathrm{F}_{(7,135)}=1.528 ; p=0.206$, with a low effect size $(d=0.054 ; r=0.06)$.

\subsubsection{Effects on Subjective Well-Being}

The posttest phase results (ANCOVA) (refer to Table 3) showed a significant increase in positive affect with a medium effect size $(d=0.61)$ and a significant decrease in negative affect with a low effect size $(d=0.39)$ in favor of the EG (refer to Figure 2).
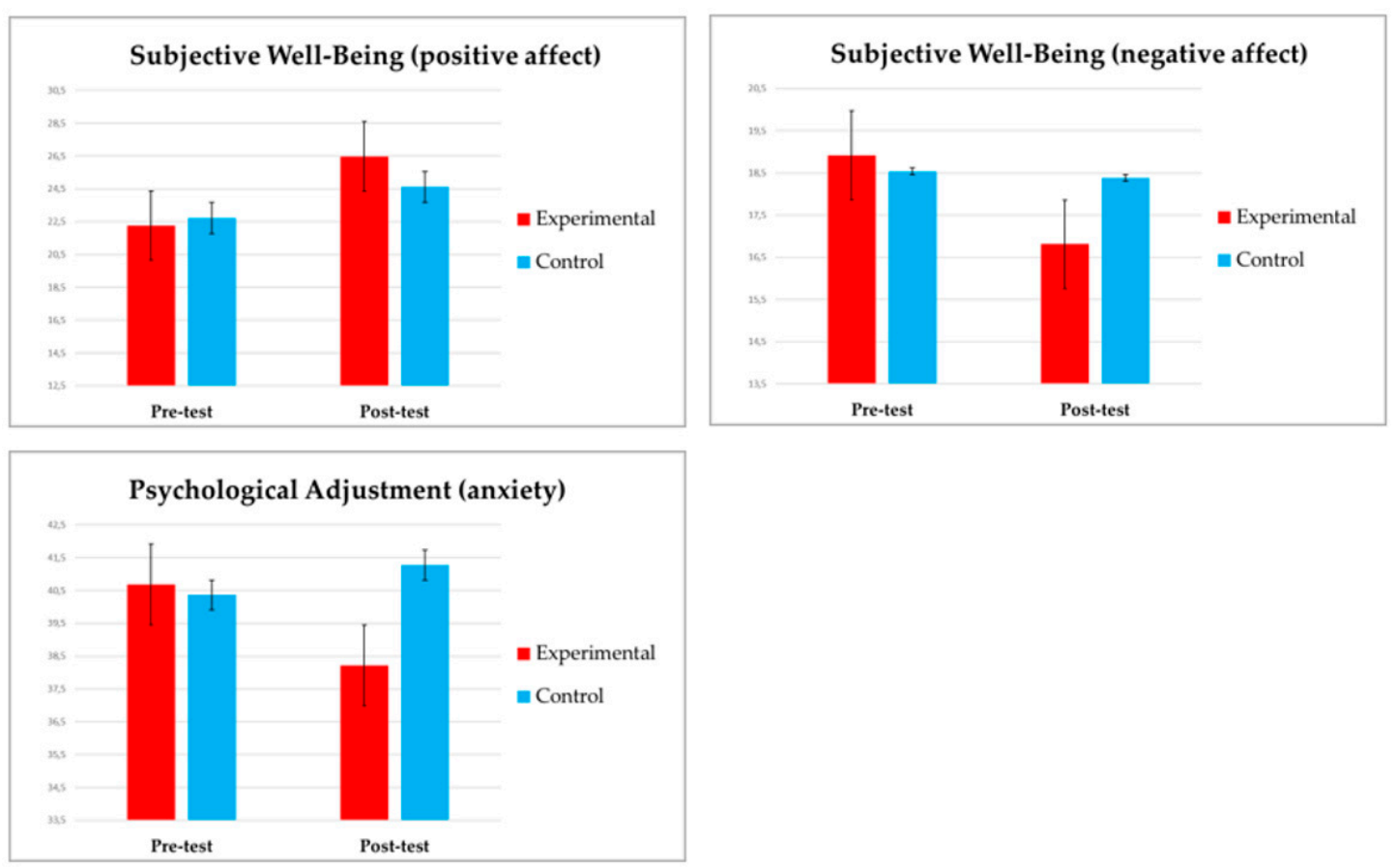

Figure 2. Significant effects of the intervention in the experimental group on the variables studied. 


\subsubsection{Effects on Psychosocial Adjustment}

After performing ANCOVA in the posttest phase, the results confirmed a significant decrease in anxiety, in favor of the experimental group, with a low effect size $(d=0.28)$ (refer to Figure 2). However, no significant differences were confirmed in the other variables analyzed, depression, and social stress (refer to Table 3).

\section{Discussion}

In recent years, different authors $[24,31,35]$ present the interest of research to continue examining the impact of healthy and active practices in the school context. In this sense, the present study evaluated the impact in children of an educational intervention based on the Sport Education model (SEM), compared to an educational intervention based on the traditional model of Direct Instruction (TM-DI) on: (1) subjective well-being in its affective dimension; and (2) psychosocial adjustment in its clinical indicators: depression, anxiety, and social stress.

The findings of this investigation confirmed statistically significant improvements in the variables under study, in favor of the experimental group (SEM) compared to the control group (TM-DI) in: (a) positive and negative affect; and (b) anxiety. However, no significant improvements were shown in the psychosocial adjustment indicators of depression and social stress.

First, the previous results confirmed that the intervention (SEM) stimulated in the experimental group a significant increase in positive affect and a significant decrease in negative affect. Therefore, Hypothesis 1 is confirmed. These results converge with other previous studies, which analyze the efficacy of SEM-based interventions on emotional or affective variables [24,31,32,40,51]. Likewise, the effect sizes, in positive affect and negative affect, are similar to those obtained in other previous investigations (e.g., [40]). A possible explanation for these results could be due to the synergy between subjective well-being with the development of physical, active, and healthy habits $[14,16,62,63]$. Similarly, the increase in physical inactivity in the school environment [14] makes beneficial the implementation of healthy and active interventions or programs $[15,22]$ through cooperative and participatory methodologies focused on the student (active subject) [27] for the well-being of the student $[40,64]$. Standage and Gillison [65] establish that proactive teaching processes, applied correctly in physical education, can improve motivation and favor positive affectivity, and therefore, the quality of life in childhood. Essential elements of the SEM, such as a real and pedagogical vision of the structure and sport organization [25], competition, enthusiasm, and physical sport culture [26,29], the positive interdependence that arises with cooperative learning [52], the affiliation or feeling of belonging [46], the choice and assignment of responsibility roles [25], and motivational indicators [34,35,47,48] could significantly reinforce the affective sphere in children [66].

Second, the results showed some improvements in psychosocial adjustment, specifically a significant decrease in anxiety, although with a low effect size. In this way, Hypothesis 2 was partially confirmed, since no significant decreases in depression and social anxiety were found. Active participation in educational intervention is likely to be positively related to well-being and negatively related to anxiety. In line with the results of some authors [8], it is concluded that participation in sport activities independently contributed to improving subjective well-being and reducing anxiety levels.

A proper analysis of psychosocial adjustment implies being able to associate this construct with other psychological variables [67] such as subjective well-being [10,11], and being able to evaluate it effectively $[12,68]$. The influence of psychosocial adjustment in the educational environment is relevant, particularly concerning the development of adaptive behaviors (positive adjustment) and maladjustment (mismatch) [11,12]. A positive adjustment in the students' behavior or personality would imply an optimal school climate in its different physical, psychological, social, and affective dimensions [13,19]. In this sense, it would be positive to promote competent pedagogical models [23] or adequate educational interventions [22], such as the SEM [21,36]. Similarly, the positive impact of the SEM at the social (e.g., [28,41]) and emotional (e.g., [40,51]) levels, as well as its beneficial and 
significant effects on social relationships and against attitudes of violence and aggressiveness [52] could lead to reinforcement in the educational field, for the development of adaptive strategies or resources, being able to effectively face the mismatch or negative psychosocial characteristics [11].

Therefore, it would be reasonable to think that essential elements of the model such as the roles of responsibilities, cooperative learning, the formal competition, and the final event, where the students were able to self-manage their learning, together with the creative, motivating, cooperative, and celebratory nature of the SEM could have influenced the participating children to improve their academic achievement in physical education. The enriching elements of the SEM included in the intervention program may also have contributed to these results, such as the self-construction of didactic materials, the interdisciplinarity of the program, and teaching with projects, since their pedagogical effectiveness has been previously verified in other studies $[50,69,70]$.

Despite these results, we must point out that the present research shows the following limitations: (1) the number of participants was limited and a convenience sampling was used, which may limit the generalization of the results to other populations; (2) the variables under study were evaluated with self-reports. It would be advisable to support these results with other hetero-informed instruments; (3) it would be advisable to carry out a follow-up evaluation; (4) it would be necessary to evaluate the dynamics generated in the development of the sessions (formative evaluation) [71]; (5) difficulties in following some recommendations to start the SEM during the teaching sessions. The organization and initial grouping of the teams, follow-up of the participating students due to illness or injury, weather, facilities, equipment, and/or teacher availability are some of the aspects that could hinder the follow-up and development of the sessions [37].

On the other hand, future lines of research could be directed towards: (1) expanding the sample and diversifying educational contexts, in addition to the socio-cultural environment of the participants; (2) evaluation of the effects of educational intervention on other psychological (e.g., interpersonal relationships, self-esteem, or self-concept) or clinical (e.g., cortisol) variables.

\section{Conclusions}

Sierra-Díaz et al. [35] establish that physical education could be considered a relevant subject to promote wellness habits associated with a healthy lifestyle during sport and other types of active activities. Likewise, regarding the educational context, physical education effectively promotes the holistic development of students [31] due to its active, practical, transversal, and motivating frameworks that make it unique compared to other classes.

Current educational demands emphasize the need for a methodological renewal in the evolution of traditional physical education toward a more current and motivating methodological framework driven by quality physical education [14]. The current results show the benefits and efficacy in children of an intervention in physical education to improve subjective well-being, psychosocial adjustment, and school results in this subject. These findings have interesting pedagogical and empirical implications for both teachers and students. For teachers, the SEM-based intervention constitutes an effective, efficient, and motivating tool with proven positive results in physical education classes. For students, the intervention could promote well-being or quality of life, improve their socio-scholastic adaptation, and increase their autonomy, promoting positive and comprehensive development of their personalities.

In conclusion, the application of this type of intervention in the school environment is recommended for children due to the evident physical, affective, psychosocial, and academic benefits, in line with other investigations [24,31]. Furthermore, these conclusions offer empirical support for the pedagogical model of SEM and have interesting educational implications that promote the effectiveness of innovative and motivating teaching approaches.

Author Contributions: Conceptualization, P.L. and J.C.; methodology, P.L. and J.C.; software, P.L. and A.R.-D.; validation, P.L. and J.C.; formal analysis, P.L. and J.C.; investigation, P.L., A.R.-D., D.R.-R., and J.C.; resources, P.L., A.R.-D., and J.C.; data curation, P.L., A.R.-D., and J.C.; writing-original draft preparation, P.L. and D.R.-R.; 
writing-review and editing, P.L., D.R.-R. and J.C.; visualization, P.L. and J.C.; supervision, P.L. and J.C.; project administration, J.C. All authors have read and agreed to the published version of the manuscript.

Funding: This research received no external funding.

Conflicts of Interest: The authors declare no conflict of interest.

\section{References}

1. Diener, E. Subjective well-being: The science of happiness and a proposal for a national index. Am. Psychol. 2000, 55, 34-43. [CrossRef]

2. Diener, E.; Suh, E.M.; Lucas, R.E.; Smith, H.L. Subjective well-being: Three decades of progress. Psychol. Bull. 1999, 125, 276-302. [CrossRef]

3. Ryff, C.D.; Keyes, C.L.M. The structure of psychological well-being revisited. J. Pers. Soc. Psychol. 1995, 69, 719-727. [CrossRef]

4. Diener, E.; Biswas-Diener, R. Rethinking Happiness: The Science of Psychological Wealth; Blackwell Publishing: Malden, MA, USA, 2008; ISBN 978-1-4051-4661-6.

5. Sánchez-Álvarez, N.; Extremera, N.; Fernández-Berrocal, P. The relation between emotional intelligence and subjective well-being: A meta-analytic investigation. J. Posit. Psychol. 2016, 11, 276-285. [CrossRef]

6. Lyubomirsky, S.; Lepper, H.S. A measure of subjective happiness: Preliminary reliability and construct validation. Soc. Indic. Res. 1999, 46, 137-155. [CrossRef]

7. Campbell, A. The Sense of Well-Being in America: Recent Patterns and Trends; McGraw-Hill: New York, NY, USA, 1981; ISBN 978-0-07-009683-7.

8. McMahon, E.M.; Corcoran, P.; O’Regan, G.; Keeley, H.; Cannon, M.; Carli, V.; Wasserman, C.; Hadlaczky, G.; Sarchiapone, M.; Apter, A.; et al. Physical activity in European adolescents and associations with anxiety, depression and well-being. Eur. Child Adolesc. Psychiatry 2017, 26, 111-122. [CrossRef] [PubMed]

9. Diener, E.; Fujita, F. Resources, personal strivings, and subjective well-being: A nomothetic and idiographic approach. J. Pers. Soc. Psychol. 1995, 68, 926-935. [CrossRef] [PubMed]

10. Huebner, E.S.; Funk, B.A.; Gilman, R. Cross-sectional and longitudinal psychosocial correlates of adolescent life satisfaction reports. Can. J. Sch. Psychol. 2000, 16, 53-64. [CrossRef]

11. Rodríguez-Fernández, A.; Ramos-Díaz, E.; Madariaga, J.M.; Arrivillaga, A.; Galende, N. Steps in the construction and verification of an explanatory model of psychosocial adjustment. Eur. J. Educ. Psychol. 2016, 9, 20-28. [CrossRef]

12. Reynolds, C.R.; Kamphaus, R.W. Behavior Assessment System for Children (BASC-2), 2nd ed.; Pearson: London, UK, 2004.

13. Baker, J.A.; Dilly, L.J.; Aupperlee, J.L.; Patil, S.A. The developmental context of school satisfaction: Schools as psychologically healthy environments. Sch. Psychol. Q. 2003, 18, 206-221. [CrossRef]

14. United Nations Educational, Scientific and Cultural Organization [UNESCO] Quality Physical Education (QPE): Guidelines for Policy Makers—UNESCO Digital Library. Available online: https://unesdoc.unesco. org/ark:/48223/pf0000231101 (accessed on 23 January 2020).

15. Pate, R.R.; Dowda, M. Raising an Active and Healthy Generation: A Comprehensive Public Health Initiative. Exerc. Sport Sci. Rev. 2019, 47, 3-14. [CrossRef] [PubMed]

16. Biddle, S.J.H.; Fox, K.; Boutcher, S. Physical Activity and Psychological Well-Being; Routledge: London, UK, 2000; ISBN 978-0-415-23481-8.

17. Committee on Sports Medicine and Fitness and Committee on School Health Organized Sports for Children and Preadolescents. Pediatrics 2001, 107, 1459-1462. [CrossRef] [PubMed]

18. Escalié, G.; Recoules, N.; Chaliès, S.; Legrain, P. Helping students build competences in physical education: Theoretical proposals and illustrations. Sport Educ. Soc. 2017, 24, 390-403. [CrossRef]

19. Bisquerra, R.; Pérez-González, J.C.; García, E. Inteligencia Emocional en Educación [Emotional Intelligence in Education]; Síntesis: Madrid, Spain, 2015; ISBN 978-84-9077-630-8.

20. Restrepo, J.; Rivera, J. Taekwondo practice and internalizing and externalizing behaviors in children between the ages of 6 and 12. Katharsis 2017, 23, 13-32. [CrossRef]

21. Metzler, M.W. Instructional Models for Physical Education, 3th ed.; Routledge: London, UK, 2017; ISBN 978-1-934432-13-6. 
22. Shields, D.L.; Funk, C.D.; Bredemeier, B.L. Relationships among moral and contesting variables and prosocial and antisocial behavior in sport. J. Moral Educ. 2018, 47, 17-33. [CrossRef]

23. Iserbyt, P.; Ward, P.; Martens, J. The influence of content knowledge on teaching and learning in Traditional and Sport Education contexts: An exploratory study. Phys. Educ. Sport Pedagog. 2016, 21, 539-556. [CrossRef]

24. Bessa, C.; Hastie, P.; Araújo, R.; Mesquita, I. What Do We Know About the Development of Personal and Social Skills within the Sport Education Model: A Systematic Review. J. Sports Sci. Med. 2019, 18, 812-829.

25. Siedentop, D.; Hastie, P.; van der Mars, H. Complete Guide to Sport Education, 3rd ed.; Human Kinetics: Champaign, IL, USA, 2019; ISBN 978-1-4925-6251-1.

26. Kolovelonis, A.; Goudas, M. The relation of physical self-perceptions of competence, goal orientation, and optimism with students' performance calibration in physical education. Learn. Individ. Differ. 2018, 61, 77-86. [CrossRef]

27. Kirk, D. Educational value and models-based practice in physical education. Educ. Philos. Theory 2013, 45, 973-986. [CrossRef]

28. Pan, Y.H.; Huang, C.H.; Lee, I.S.; Hsu, W.T. Comparison of Learning Effects of Merging TPSR Respectively with Sport Education and Traditional Teaching Model in High School Physical Education Classes. Sustainability 2019, 11, 2057. [CrossRef]

29. Hastie, P.A.; Martinez de Ojeda, D.; Calderón Luquin, A. A review of research on Sport Education: 2004 to the present. Phys. Educ. Sport Pedagog. 2011, 16, 103-132. [CrossRef]

30. Wallhead, T.; O'sullivan, M. Sport Education: Physical education for the new millennium? Phys. Educ. Sport Pedagog. 2005, 10, 181-210. [CrossRef]

31. Evangelio, C.; Sierra-Díaz, M.J.; González-Víllora, S.; Fernández-Rio, F.J. The sport education model in elementary and secondary education: A systematic review. Movimento 2018, 24, 931-946. [CrossRef]

32. González-Víllora, S.; Evangelio, C.; Sierra-Díaz, J.; Fernández-Río, J. Hybridizing pedagogical models: A systematic review. Eur. Phys. Educ. Rev. 2018, 25, 1056-1074. [CrossRef]

33. Harvey, S.; Kirk, D.; O'Donovan, T.M. Sport Education as a pedagogical application for ethical development in physical education and youth sport. Sport Educ. Soc. 2014, 19, 41-62. [CrossRef]

34. Chu, T.L.; Zhang, T. Motivational processes in Sport Education programs among high school students: A systematic review. Eur. Phys. Educ. Rev. 2018, 24, 372-394. [CrossRef]

35. Sierra-Díaz, M.J.; González-Víllora, S.; Pastor-Vicedo, J.C.; López-Sánchez, G.F. Can we motivate students to practice physical activities and sports through models-based practice? A systematic review and meta-analysis of psychosocial factors related to physical education. Front. Psychol. 2019, 10, 2115. [CrossRef]

36. González-Víllora, S.; Sierra-Díaz, M.J.; Pastor-Vicedo, J.C.; Contreras-Jordán, O.R. The way to increase the motor and sport competence among children: The contextualized sport alphabetization model. Front. Physiol. 2019, 10, 569. [CrossRef]

37. Hastie, P.A.; Casey, A. Fidelity in models-based practice research in sport pedagogy: A guide for future investigations. J. Teach. Phys. Educ. 2014, 33, 422-431. [CrossRef]

38. Araújo, R.; Hastie, P.; Lohse, K.R.; Bessa, C.; Mesquita, I. The long-term development of volleyball game play performance using Sport Education and the Step-Game-Approach Model. Eur. Phys. Educ. Rev. 2019, 25, 311-326. [CrossRef]

39. Wahl-Alexander, Z.; Chomentowski, P. Impact of a university physical conditioning sport education season on students' fitness levels. Health Educ. J. 2018, 77, 828-836. [CrossRef]

40. Luna, P.; Guerrero, J.; Cejudo, J. Improving Adolescents' Subjective Well-Being, Trait Emotional Intelligence and Social Anxiety through a Programme Based on the Sport Education Model. Int. J. Environ. Res. Public. Health 2019, 16, 1821. [CrossRef] [PubMed]

41. Kao, C.C. Development of team cohesion and sustained collaboration skills with the Sport Education Model. Sustainability 2019, 11, 2348. [CrossRef]

42. Perlman, D. Change in affect and needs satisfaction for amotivated students within the Sport Education Model. J. Teach. Phys. Educ. 2010, 29, 433-445. [CrossRef]

43. Farias, C.F.; Mesquita, I.; Hastie, P.A. Game performance and understanding within a hybrid Sport Education season. J. Teach. Phys. Educ. 2015, 34, 363-383. [CrossRef]

44. Ward, J.K.; Hastie, P.A.; Wadsworth, D.D.; Foote, S.; Brock, S.J.; Hollett, N. A Sport Education Fitness season's impact on students' fitness levels, knowledge, and in-class physical activity. Res. Q. Exerc. Sport 2017, 88, 346-351. [CrossRef] 
45. Pereira, J.; Hastie, P.; Araújo, R.; Farias, C.; Rolim, R.; Mesquita, I. A comparative study of students' track and field technical performance in sport education and in a direct instruction approach. J. Sports Sci. Med. 2015, 14, 118-127.

46. Browne, T.B.J.; Carlson, T.B.; Hastie, P.A. A Comparison of rugby seasons presented in traditional and sport education formats. Eur. Phys. Educ. Rev. 2004, 10, 199-214. [CrossRef]

47. Cuevas, R.; García-López, L.M.; Serra-Olivares, J. Sport education model and self-determination theory: An intervention in secondary school children. Kinesiology 2016, 48, 30-38. [CrossRef]

48. Gil-Arias, A.; Harvey, S.; Cárceles, A.; Práxedes, A.; Del Villar, F. Impact of a hybrid TGfU-Sport Education unit on student motivation in physical education. PLoS ONE 2017, 12, e0179876. [CrossRef]

49. Cuevas, R.; García-López, L.M.; Contreras, O. Influence of the Sport Education Model in the psychological basic needs. Cuad. Psicol. Deporte 2015, 15, 155-162. [CrossRef]

50. Knowles, A.; Wallhead, T.L.; Readdy, T. Exploring the synergy between Sport Education and in-school sport participation. J. Teach. Phys. Educ. 2018, 37, 113-122. [CrossRef]

51. Méndez-Giménez, A.; Martínez de Ojeda, D.; Valverde-Pérez, J.J. Emotional intelligence and motivational mediators in a season of Sport Education Mime. Ágora Para Educ. Física Deporte 2017, 19, 52-72. [CrossRef]

52. Menéndez-Santurio, J.I.; Fernández-Río, J. Violence, responsibility, friendship and basic psychological needs: Effects of a Sport Education and Teaching for Personal and Social Responsibility program. Rev. Psicodidáct. 2016, 21, 245-260. [CrossRef]

53. Pérez-González, J.C.; Qualter, P. Emotional intelligence and emotional education in the school years. In An Introduction to Emotional Intelligence; Dacree Pool, L., Qualter, P., Eds.; Wiley: Chichester, UK, 2018; pp. 81-104. ISBN 978-1-119-11442-0.

54. Watson, D.; Clark, L.A.; Tellegen, A. Development and validation of brief measures of positive and negative affect: The PANAS scales. J. Pers. Soc. Psychol. 1988, 54, 1063-1070. [CrossRef]

55. Sandín, B. Escalas PANAS de afecto positivo y negativo para niños y adolescentes (PANASN). Rev. Psicopatol. Psicol. Clín. 2003, 8. [CrossRef]

56. González, J.; Fernández, S.; Pérez, E.; Santamaría, P. Adaptación Española del Sistema de Evaluación de la Conducta en Niños y Adolescentes: BASC.; TEA: Madrid, Spain, 2004; ISBN 978-84-16231-16-4.

57. Sinelnikov, O.A. Sport Education for teachers: Professional development when introducing a novel curriculum model. Eur. Phys. Educ. Rev. 2009, 15, 91-114. [CrossRef]

58. García-López, L.M.; Gutiérrez, D. Aprendiendo a Enseñar Deporte. Modelos de Enseñanza Comprensiva y Educación Deportiva; 2a ; INDE Editorial: Barcelona, Spain, 2016; ISBN 978-84-9729-374-7.

59. Méndez-Giménez, A.; Fernández-Río, J.; García-López, L.M.; González-Víllora, S.; Gutiérrez, D.; Martínez, J.; Sánchez, R. Modelos Actuales de Iniciación Deportiva: Unidades Didácticas Sobre Juegos y Deportes de Cancha Dividida; Wanceulen Editorial Deportiva: Sevilla, España, 2011; ISBN 978-84-9823-827-3.

60. Burgueño, R.; Medina-Casaubón, J.; Morales-Ortiz, E.; Cueto-Martín, B.; Sánchez-Gallardo, I. Sport Education versus Traditional Teaching: Influence on motivational regulation in High School students. Cuad. Psicol. Deporte 2017, 17, 87-98.

61. Cohen, J. Statistical Power Analysis for the Behavioral Sciences, 2nd ed.; L. Erlbaum Associates: Hillsdale, NJ, USA, 1988; ISBN 978-0-8058-0283-2.

62. Sánchez-López, M.; Cavero-Redondo, I.; Álvarez-Bueno, C.; Ruiz-Hermosa, A.; Pozuelo-Carrascosa, D.P.; Díez-Fernández, A.; Gutierrez-Díaz del Campo, D.; Pardo-Guijarro, M.J.; Martínez-Vizcaíno, V. Impact of a multicomponent physical activity intervention on cognitive performance: The MOVI-KIDS study. Scand. J. Med. Sci. Sports 2019, 29, 766-775. [CrossRef]

63. Bailey, R. Physical education and sport in schools: A review of benefits and outcomes. J. Sch. Health 2006, 76, 397-401. [CrossRef]

64. Whitehead, M. Physical Literacy: Throughout the Lifecourse; Routledge: London, UK, 2010; ISBN 978-0-203-88190-3.

65. Standage, M.; Gillison, F. Students' motivational responses toward school physical education and their relationship to general self-esteem and health-related quality of life. Psychol. Sport Exerc. 2007, 8, 704-721. [CrossRef]

66. Sandford, R.A.; Duncombe, R.; Armour, K.M. The role of physical activity/sport in tackling youth disaffection and anti-social behaviour. Educ. Rev. 2008, 60, 419-435. [CrossRef] 
67. De la Torre-Cruz, M.; Casanova, P.F.; Villa-Carpio, M.; Cerezo, M.T. Consistencia e inconsistencia parental: Relaciones con la conducta agresiva y satisfacción vital de los adolescentes. Eur. J. Educ. Psychol. 2013, 6, 135-149. [CrossRef]

68. Fernández-Berrocal, P.; Ruiz-Aranda, D.; Salguero, J.M.; Palomera, R.; Extremera, N. The relationship of Botín Foundation's Emotional Intelligence Test (TIEFBA) with personal and scholar adjustment of Spanish adolescents. Rev. Psicodidáct. 2018, 23, 1-8. [CrossRef]

69. Méndez-Giménez, A.; Martinez de Ojeda, D.; Valverde-Pérez, J.J. Students and teachers assessment of conventional and self-made material: Longitudinal crossover study in physical education. Retos 2016, 30, 20-25.

70. Lleixà, T.; González-Arévalo, C.; Braz-Vieira, M. Integrating key competences in school physical education programmes. Eur. Phys. Educ. Rev. 2016, 22, 506-525. [CrossRef]

71. Práxedes, A.; Del Villar Álvarez, F.; Moreno, A.; Gil-Arias, A.; Davids, K. Effects of a nonlinear pedagogy intervention programme on the emergent tactical behaviours of youth footballers. Phys. Educ. Sport Pedagog. 2019, 24, 332-343. [CrossRef]

(C) 2020 by the authors. Licensee MDPI, Basel, Switzerland. This article is an open access article distributed under the terms and conditions of the Creative Commons Attribution (CC BY) license (http://creativecommons.org/licenses/by/4.0/). 